\title{
CSR Inflections: An Overview on CSR Global Strategies Adopted by Companies in Malaysia and Other Asian Countries
}

\author{
Naila Aaijaz and Mohamed Dahlan bin Ibrahim
}

Faculty of Entrepreneurship and Business University Malaysia Kelantan (UMK), Malaysia

\begin{abstract}
Since the early 2000s, the conversation on CSR in Malaysia has been moving ahead rapidly. Whereas commentators tended to understand CSR in the 1990s as exclusively dealing with supplying chain issues, the last few years have seen changing expectations on company performance when it comes to social and environmental issues.
\end{abstract}

In this paper, the researchers have tried to focus on a handful of key changes in the way various groups perceive good company practices, and outline some of the key challenges and opportunities in the CSR area.

In a developing and progressive country like Malaysia, CSR stands to be of vital importance for a mutual and symbiotic growth. The growth defined is not only for the individual but for the society as a whole and country at large.

The paper investigates:

- Magnitude of CSR advocated through company websites

- Awareness of CSR in Malaysia based on internet usage

- Impacts of globalization

- CSR : An active approach in Japan and other Asian countries

Keywords: Malaysia, Corporate Social Responsibility , Internet users, Stakeholders.

\section{Introduction}

Corporate Social Responsibility (CSR) is often referred to as Business Responsibility and an organization's response on environmental, social and economic issues. Positive actions that reduce the negative impact of an organization on these issues can be seen as a way of managing risk. Corporate reputation, Governance and Ethics are headline issues associated with CSR that have made the news headlines in the last few years. Business Ethics, being a vital part of Modern Concept of CSR, which has been low profile in Business Publication and Business School Curriculum, has suddenly gained status. The word, "ETHICS" was once considered irrelevant by corporate loyalists but now discussion of it is increasingly seen as not only important but also critical to a company's success.

Business Analysts in developing countries have come to a conclusion that Ethical subjectivism, relativism, consequentialism

Copyright (C) 2012 Naila Aaijaz and Mohamed Dahlan bin Ibrahim. This is an open access article distributed under the Creative Commons Attribution License unported 3.0, which permits unrestricted use, distribution, and reproduction in any medium, provided that original work is properly cited. Contact author: Naila Aaijaz E-mail: naila@umk.edu.my, eco.doctor@gmail.com 
and virtue are important to develop a positive attitude towards resolution of conflicts and development of industries.

Globalization has brought a challenge as well as an opportunity for the Malaysian companies. Companies here are now facing competition from multinational corporations. This is a challenge. But there is an opportunity. Globalization does not simply mean allowing foreign capital and foreign technology in India. It also means creating Malaysian companies on a global scale, in terms of both investment and trade.

In the context of globalized finance, Malaysian companies are no longer limited to the modest size of the domestic capital market and can tap the huge global market through EURO - issues and sales to Foreign institutional investors in Malaysia. Globalization has also offered significant possibilities for Malaysia's greater participation in world trade. As it does not have a fair share of the world's reserves in some natural resources,now.Now it has access to international capital market. This may give the country a competitive advantage in international trade. This has placed a whole new set of capabilities in the hands of consumers and businesses. Today consumers have:

1. A substantial increase in buying power,

2. A greater variety of available goods and services,

3. A greater amount of information about practically anything,

4. A greater ease in interacting and placing and receiving orders,

5. An ability to compare notes on products and services

These benefits have come in the way of consumers because with continuous change and development, the society is becoming literate. This literacy of the society has led to the development of a concept called "Corporate Social Responsibility (CSR)".

\section{CSR and Philanthropy - The Confusion Continues...}

In Malaysia, it is being clearly seen that the ground realities like unemployment, availability of basic amenities, corruption, poverty, education, etc... are not being looked into "practically". The viability of the Government schemes and projects is under the scanner. The question that arises at this juncture - Is it the responsibility only of the government?

From the viewpoint of renowned academicians, both the Public and the Private Sector have to play a major role. To create an increasing database of customers, the concept of an all round CSR needs to be put in place.

CSR may have become a hot topic in some management circles for the past few years, but for a significant proportion of ordinary employees it is completely irrelevant. This is because CSR has not been made to understand down the line.

\section{CSR is More than Philanthropy}

CSR is a component of good corporate governance (CG). To ensure sustainability, a company needs to integrate CSR into its core practices.... Many companies have the wrong notion that CSR is just signing cheques for charities. CSR is more than that. For example, engineers in a company could be engaged to give maths tuition at an orphanage.

\section{What is CSR?}

CSR can be well understood under the "3 waves of CSR":.

\section{a. Community engagement}

b. Socially responsible production process

\section{c. Socially responsible employee relations}

It could be clearly analyzed under the "3 waves of CSR" that the corporate world needs to shell out a part of its profit initially to tap the long run economies of scale ( LREoS), be it internal or external. 
Beyond good intentions, some of the benefits that the corporate world reaps are:

- Powerfully aligning the firms operations and social environmental "Foot print" with managements values,

- Understanding and transforming public perception of the company and industry,

- Attracting investment in the firm, sector and overall economy,

- Increasing market share and new market penetration,

- Mobilizing and energizing the company's own human capital,

\section{- Reducing risk}

Many companies use the strategy of benchmarking to compete with their respective industries in CSR policy, implementation, and effectiveness. Benchmarking involves reviewing competitor CSR initiatives, as well as measuring and evaluating the impact that those policies have on society and the environment, and how customers perceive competitor CSR strategy. After a comprehensive study of competitor strategy and an internal policy review performed, a comparison can be drawn and a strategy developed for competition with CSR initiatives.

\section{Literature Review}

What is Corporate Social Responsibility? Many people have a vague idea what it is about: a big corporation giving some money to the environment or a community initiative. Often CSR is thought to be nothing more than a cynical PR opportunity, a way for MegaCorp to gloss over its dumping of chemicals into a nature reserve by spending a few dollars on a youth centre (Ameinfo,2005). CSR is defined as open and transparent business practices that are based on ethical values and respect for the community, employees, the environment, shareholders and other stakeholders (Bursa Malaysia, 2008). The Dow Jones Sustainability Index (2005) web site as cited by Holcomb et al (2007) defines corporate sustainability as follows:

Corporate sustainability is a business
approach that creates long-term
shareholder value by embracing opportunities and managing risks deriving from economic, environmental and social developments. Corporate sustainability leaders achieve long-term shareholder value by gearing their strategies and management to harness the market's potential for sustainability products and services while at the same time successfully reducing and avoiding sustainability costs and risks.

One of the more cited definitions of CSR is proposed by Carroll (1979) as cited by Holcomb et al (2007). He states that businesses that practice social responsibility attend to "economic, legal, ethical, and discretionary (philanthropic) expectations that society has of organizations at a given point in time". Consequently, CSR is frequently linked to such constructs as business ethics, corporate citizenship, stakeholder engagement, sustainable development, corporate governance, sustainable finance, and social responsible investment, et cetera (Amaeshi and Adi, 2007 as cited by Amaeshi et al (2007)

Corporate social responsibility has many facets. CSR is when a company or an organization strikes a balance between profitability and contributions to the societies in which they operate and being obligated to meet the expectations of stakeholders, who are the sources of the legitimacy of the organization. The stakeholders include the owners, investors, employees, customers, government, suppliers, competitors and the community (Suza, 2005). Today, many organizations have joined the bandwagon in realizing their CSR agendas; from a very simple charity of donating to welfare institutions to a more sophisticated activity like protecting endangered wildlife such as the hawksbills turtle. Generally, the main areas of corporate responsibility are the social, economic and moral responsibilities of the firm, as well as the management of the corporate responsibility activities of 
businesses (Cannon, 1992 cited by Piacentini et al, 2000).

Companies involved in strategic CSR develop policies and programs in areas such as employee relations, community development, environmental stewardship, international relationships, marketplace practices, fiscal responsibility and accountability (Amaeshi and Adi, 2006). In Malaysia, there is no universal approach to CSR. Companies are free to adopt what suits them. However, there are some basic concepts that cut across all definitions and these should be considered in crafting a company's CSR vision (Bursa Malaysia, 2008). Perhaps in view of the fallout from giant companies' scandals, image building appears to be a primary motivating factor for companies to involve with Corporate Social Responsibility (CSR) and one of the CSR facets is the corporate environmental reporting (Sharifah Buniamin et al,2008).

Nurhayah et al (2006), emphasize that in Malaysia the development of CSR has, since olden times, moved to higher levels and Malaysia is recognized as being among the most active emerging economies in relation to corporate responsibilities. Companies are increasingly recognizing CSR as a business priority (CSR Status Report, 2007). Businesses now recognize the value of ensuring sustainability as ae long-term approach rather than a short-term one, which thereafter leaves companies open to social and environmental risks. Many companies are looking for CSR commitments to find appropriate partners and forge ahead with better business networking.

\section{The Development of Corporate Social Responsibilty(CSR) in Malaysia}

\section{CSR Reporting}

In the past, corporate reporting traditionally has tended to focus on financial information to investors. The voluntary reporting of environmental impacts and initiatives in company annual reports has become widespread among organisations accepting an obligation to extend their environmental responsibilities beyond regulatory compliance (Brophy and Starkey 1996; Collier (1995) as cited by Goliath (2004). Accordingly, businesses wishing to respond to this increased public concern about CSR may use the annual report as a means of communication (Nik Nazli et al , 2003). Nielsen and Thomsen (2007) also mentioned that in some European countries, including Denmark, governments and legislators recommend that organisations should report on their social and environmental activities (cf. the Danish law on Organisational Annual Reporting of 2002) in connection with the general annual report. Claims for transparency and accountability from organizations operating worldwide have pushed them to put corporate social responsibility (CSR) on the agenda.

Information on environmental and social issues is commonly communicated by companies either as a section in their annual reports or stand-alone reports. Stand-alone reports are hard copy only. Some organizations have chosen to communicate about their social policy and activities on their corporate websites using distinct and inconsistent concepts for similar issues (Nielsen and Thomsen, 2007). This is in the form of Internet-based only or, most commonly, provided in hard copy format as well as being put on the Internet (Adams 2002, Adams and Frost 2004). From a study, researchers found that 98 percent of U.K-based companies, 85 percent of the U.S. companies and 56 percent of the Australian companies had CSR disclosures in their annual reports. About $80 \%$ of FTSE-100 companies now provide information about their environmental performance, social impact, or both (Amaeshi, 2006).

However, in Malaysia the reporting of CSR in the annual reports is still in the state of progressing. According to an ACCA (Association of Chartered Certified Accountants, Malaysia) report entitled The State of Corporate Environmental Reporting in Malaysia, published in early 2002, CSR in Malaysia is in its infancy (Goliath, 2004). Of course this trend will gradually become a norm in the coming years as the Kuala Lumpur Stock Exchange 
has given the hint that listed companies will do the same. As mentioned by the CEO of KLSE ,they are looking into crafting a CSR statement in their annual report Annual Report (Bursa Malaysia, 2007). Companies in Malaysia have expanded their annual reports beyond the traditional reporting by incorporating elements of environmental ,social, product and employee information Bursa Malaysia, 2008). Yusli Mohamed Yusoff, Chief Executive Officer of Bursa Malaysia commented, that a good CSR practices promote business sustainability and add value to capital markets as well as the standing of our companies.

The environmental reporting or sometime known as "green reporting" is one of the facets of voluntary social reporting included in the financial statements. Vitally, CSR involves communicating the company's actions withits stakeholders and encouraging their feedback. Only in this way can a company have a dynamic and relevant CSR vision (Bursa Malaysia, 2008). According to OWW Consulting Malaysia (2008), reporting of CSR activities does benefits in many ways. The benefits vary from helping stakeholders on CSR performance,showing value added on yearon year improvements, to helping for internal strategy to assess, monitoring as well as reporting CSR. Finally, CSR reports include investor relation toward educating the investors and realizing its importance. Other forms of voluntary social reporting include value added statements, corporate social responsibility and accountability disclosures (Zauwiyah et al, 2003).

Given that CSR can be difficult to quantify, communications are important to show the quality of such commitments (Macleod ,2001) and offer a means of evaluating the full impact of doing business (GRI, 2002) as cited by Ramasamy \& Wuon Ting (2004). Generally, the general public's perspective there is a way by which to gauge a company's involvement of corporate socially responsible actions concerning social, environmental compliance, and other philanthropy practices. In the US, Generally Accepted Accounting Principles (GAAP) provides regulations regarding the disclosure of company financial information within the public domain (Defoe and Falk, (1998) as cited by Holcomb et al (2007). However, there is no statutory requirement in Malaysia for public-listed companies to disclose information relating to their CSR activity (Ramasamy \& Wuon Ting, 2004). Nik Nazlli et al (2003) also noted that in Malaysia, there are presently no accounting standards for disclosing CSR information. In the absence of such standards, CSR disclosures in Malaysia would be entirely voluntary in nature. Thus, companies have full discretion as to annual report disclosure.

\section{Would a CSR Index in Malaysia Really Work?}

Corporate Social Responsibility or CSR has attracted a lot of attention in Malaysia recently. The Malaysian Prime Minister used CSR as part of his budget changes. Bursa Malaysia (the Malaysian stock exchange) has also set out an ambitious framework for listed companies in Malaysia to take CSR more seriously.

But how would we know if companies have good CSR practices or not? In other countries, companies can join a CSR Index, such as FTSE4GOOD or the Dow Jones Sustainability Index. This allows investors insight into companies which have good CSR.

Is there really any good CSR happening in Malaysia? Some recent research and newspaper articles suggest that there is more CSR in Malaysia than people think. So it would seem that the only real problem is in finding a CSR rating for Malaysian companies. It would be good if we could get a clearer idea of how CSR in Malaysia is really developing. Perhaps we could then have a CSR Index in Malaysia which would allow us to track share prices in Socially Responsible Investments in the Malaysian market.

Bursa Malaysia, the Malaysian Stock Exchange has designed a CSR framework for public listed companies in Malaysia. The website defines CSR as follows:- 
"First, let us take a look at what CSR means. It is not about how a firm spends money, but about how the firm makes money. CSR is defined as open and transparent business practices that are based on ethical values and respect for the community, employees, the environment, shareholders and other stakeholders. It is designed to deliver sustainable value to society at large. CSR supports Triple Bottom Line reporting which emphasises the economic, social and environmental bottom-line wellness. CSR goes beyond compliance to laws. And we wish to emphasise this. It is important to avoid a legalistic way of thinking when considering CSR. There is no universal approach to CSR. Companies are free to adopt what suits them. However there are some basic concepts that cut across all definitions and these should be considered in crafting a company's CSR vision. CSR is not about compliance or philanthropy or public relations. It often involves cultural transformation in a company as it integrates CSR concepts into its operations and decision making. Vitally, CSR involves communicating the company's actions with its stakeholders and encouraging their feedback. Only in this way can a company have a dynamic and relevant CSR vision. The Bursa Malaysia CSR Framework looks at 4 main focal areas for CSR practice. They are: the Environment, the Workplace, the Community and the Marketplace, in no order of priority".

\section{Research Methodology}

\section{Hypothesis Development}

This paper addresses three main hypotheses related to CSR in Malaysia: -

- Hypothesis 1 : Magnitude of CSR advocated by Malaysian corporate sector is relatively low.

- Hypothesis 2 : CSR awareness is dependent on internet usage in a country.

- Hypothesis 3 : Impact of globalization will uplift CSR activities in Malaysian companies.

\section{Methodology Adopted to Analyze the Hypotheses}

This study uses content analysis as a technique to identify and describe patterns of the inflitration of CSR website reporting. $\mathrm{CSR}$ as we know is being reported through company websites on the internet. To be moreprecise, the websites of awardwinning (Prime Ministers CSR Award 2010) companies in each of the category of honour given below (Table 1.0) are analysed. On finding CSR information, companies are designated as 'CSR advocating companies.'

\section{Hypothesis 1 - Magnitude of CSR Advocated by Malaysian Corporate Sector is Relatively Low.}

It is rather difficult to come up with a uniform analysis with which to precisely specify the extent of CSR being advocated by companies in Malaysia.Bursa Malaysia has made CSR reporting mandatory in respect of annual reports of listed companies with financial years ending on or after 31 December 2007. The extent of CSR advocating can be measured by the companies dedication towards their goal, for instance the following companies were honoured for their meritorious services towards CSR in the PrimeMinister's CSR Awards 2010 .The overall winner was the Sunway Group.

We can somehow also quantify the magnitude by observing the CSR reporting and practicing. Some companies reported CSR in context with general company communications, others were in dedicated reports. Here the authors have tried to distinguish the PLC's advocating and practicing CSR at the different levels (Source: CSR in Malaysian PLC'S, 2007 Status Report, An Executive Summary):-

The CSR Survey conducted among Malaysian Public Listed Companies (PLC's) and Multi National Companies (MNC's) revealed substantial difference in the efforts undertaken by PLC's in corporate CSR practices. The results showed that leading PLC's operating in Malaysia are integrating CSR across their business. 
However, most PLC's received low scores and lag far behind, lacking awareness, understanding of CSR concepts and CSR issues relevant to their operations. The main findings are as follows:

- $11.5 \%$ fall into the Poor band

- $28.5 \%$ fall into the Below Average band

- $27.5 \%$ fall into the Avergae band

- $19 \%$ fall into the Above Average band

- $9 \%$ fall into the Good band

- $4.5 \%$ are in the Leading band $(67 \%$ of this $4.5 \%$ were MNC's)

\section{Conclusions and Suggestions on Improving CSR Standards}

- According to the CSR Survey Report on an average, the companies assessed fall far behind international best practices and needed to increase their levels of CSR disclosure and practice.

- Nearly two-third PLC's are either average, below average or poor.

- The 4.5\% PLC's are close to international best practices benchmark.

- MNC's listed in Malaysia scored best on the survey ,comprising $67 \%$ of the $4.5 \%$ "leading" group of PLC's and $17 \%$ of the 9\%"good" PLC's.

Hence, hypothesis 1 is found to be true. Magnitude of CSR advocated and adopted by malaysian companies is low but increasing slowly.

\section{Hypothesis 2 - CSR Awareness is Dependent on Internet Usage in a Country.}

The Challenges from the Internet - In 2000, there were only 3.7 million Internet users in Malaysia against a population of 24.6 million, but the number swelled to nearly 15 million (59\% of the population) in 2008. These figures, released by the Malaysian Communications and
Multimedia Commission reveal the importance of the Internet to the Malaysian population at large.

Although back in the 1990s, most of the companies in the telecommunications sector were seriously affected by the economic crisis, there has been generally strong growth in the sector over the last decade. Fixed-line services jumped from around 2 million in 1990 to about 4.7 million (penetration of 20\%) in 2002, but there has been virtually no growth since. However, the mobile market has seen more spectacular growth, jumping from 3 million subscribers in 1999 to reach around 28 million by the end of 2008 . The trend has been on the upward swing since 2005 as Malaysia moved towards advanced information, communications and multimedia services. Broadband services providers such as TM see this as an encouraging growing trend, where most of the Internet subscribers are now eyeing for high speed broadband infrastructure.

The country's demographics have also shifted to a younger population as well. According to Malaysia Printing \& Supporting Industries Directory - editorial 2009 , as of $2008,63.5 \%$ of the country's population is between the ages of 15 and 64 , while the other $32 \%$ are below 15 years old. From as young as seven or eight years old, most young Malaysians would have some exposure to the world of Information Technology. There is no doubt that Malaysians are increasingly becoming more IT savvy and the future may see more e-books being published which are more easily and widely accessible, considering lower costs of production, and people are even now depending more on the Internet news websites to obtain the latest worldwide news at the click of the button. One such example is Malaysiakini which keeps the country updated on the latest development involving any issues. This proves our contention in Hypothesis 2 that it is true, increasing internet usage and awareness on CSR are directly proportional to each other.

Since companies need to build and nurture relationships with stakeholders, they must 
know how to strategically manage and organize activities aimed at their stakeholders (which includes customers and the public who use internet). Internet Reporting is one of the activities used by companies in a strategic and instrumental manner (Nielsen and Thomsen, 2007). The most important point here is that the reporting of CSR activity in both the annual reports and dedicated corporate websites is not only for the public knowledge but also forfulfilling the requirement set by Bursa Malaysia (stock Exchange Malaysia) to report companies' corporate social responsibility related activities.

\section{Hypothesis 3 : Impact of globalization will uplift CSR Activities in Malaysian Companies.}

\section{Acid Test of CSR - The Global Investment Trends}

Studies have shown that there is a positive correlation between companies that have sound CSR practices and their share price performance. Many international socially responsible indices have also emerged like the Dow Jones Social Index, FTSE4Good and the Jantzi Social Index, all of which are profiling the world's best CSR companies to attract socially responsible investment funds, which now amount to a figure in excess of US\$ 3 trillion. In countries like the United Kingdom, it is mandatory for pension funds to apportion some of their funds in CSR companies.

Many internationally recognized elements of good CSR can be applied globally, such as :protection of the environment, contributions to local communities, ethical procurement and non-discriminatory policies. Nevertheless, CSR by definition must be viewed in the context of the community and environment in which the corporation operates. Thus, the priorities for CSR in Malaysia context, should take into consideration the nation's social aspirations and socio-economic objectives. In this regard, YAB Prime Minister in the Budget 2007 speech had identified examples of good CSR such as -: developing local and Bumiputera vendors, ensuring ethnic diversity of employment, developing human capital through adopting school programmes, as well as supporting charitable institutions, like drug rehabilitation centers.

Moreover, based on UNCTAD's (United Nations Conference on Trade and Development) Global Investment Trends Monitor: Global And Regional Foreign Direct Investment (FDI) Trends in 2010 report has shown that the total FDI inflow of US\$7 billion (US\$1=RM3.00) into Malaysia was recorded last year compared with US $\$ 1.4$ billion in 2009 . The report was released on Jan 17, 2011.

We find that there is an impressive growth of 409.7 per cent which is the highest recorded in the region as well as among the 153 economies surveyed by UNCTAD. UNCTAD figures reaffirmed his statement on Dec 11, 2010 that Malaysia recorded significant FDI inflows amounting to US\$5.4 billion between January and September based on the data released by the Statistics Department.

Hence, our hypothesis 3 is true as the acid test is successful. This was possible as some stock exchanges promulgated CSR guidelines, principles of good corporate governance or best practice recommendations. For example:-

- Bursa Malaysia introduced a CSR Framework in 2006, evaluated the quality of CSR reporting in Malaysia and published a detailed report on companies' progress in 2008.

Bursa Malaysia falls into the category of "sustainable global stock exchanges" according to the report submitted by UNCTAD on Sustainable Stock Exchanges Real Obstacles, Real Opportunities and presented in the World Investment Forum in China, 2010.

\section{The Bursa Malaysia Framework (The Malaysian Exchange)}

The Bursa Malaysia (Malaysian Stock Exchange) CSR framework suggests that:- 
1. First, the framework has incorporated criteria drawn from the Malaysian national aspirations and policies. Thus providing Public Limited Companies (PLC's) with guidelines for building CSR initiatives that are in line with the national goals. For example, its community segment identifies education as a possible area for PLC focus, complementing thegovernment's call for the private sector adoption of schools. Under the marketplace segment, ethical procurement and vendor development initiatives are also qualified as sanctioned CSR focus areas.

2. Secondly, the disclosure framework is very flexible. At a minimum, PLCs are required to include a CSR statement in their annual reports. However, the suggested elements and content of the CSR statement are strictly voluntary. At best, the framework gives PLCs clear guidelines and actionable ideas for implementing their own CSR initiatives. The intention is to raise the awareness of CSR and encourage PLCs to integrate the practice of CSR as part of the way they work and think. The quality of the PLCs will, thus, surely improve.

3. Lastly, the framework Bursa Malaysia is introducing is a set of guidelines, and not a step-by-step prescription. This is critical if companies are going to develop meaningful CSR agendas, policies and initiatives. Just as in business, no one CSR template will fit all PLCs. Every company has a mandate to conduct its own self-examination and identify its individual areas of relevance within the CSR framework Bursa Malaysia has drawn up. Find your own passion that will help drive your business and build your own niche.

\section{A Brief Comparison on the State of CSR Reporting in Deveoped Nations like Japan and other Asian Countries}

The study presents an analysis on Japanese CSR as reported by the top 50 companies on their home websites. The paper specifically investigates the way in which, in recent years, CSR in Japan has developed and shifted in scope. There is a marked difference with findings of a decade ago which evidenced a relative lack of understanding of CSR by Japanese firms (Wokutch ,1990) and showed that very few of the top Japanese industrial corporations disclosed socially relevant information through mandatory corporate or voluntary reports (Yamagami and Kokubu, 1991). Today, by contrast, most companies publish annual environmental reports and much more information is available that is directly relevant to issues of CSR.

In Japan, a company has long been associated with the formation of community, and thus forms the basis of society to which an individual employee belongs. In contrast to an Anglo-American model of community, in Japan both individuals and companies are members of society and hence responsible to it (Tange 2001: 102). The Japanese word for business, keiei, is a compound of the words kei, meaning 'governing the world in harmony while bringing about the wellbeing of the people', and el, meaning 'making ceaseless efforts to achieve' (Taka, 1997).

So, too, the emergence of corporate business in Japan has, from the beginning, assumed a notion of CSR. The most wellknown manifestation of this is corporate Japan's long-standing commitment to workforce welfare (Mafune ,1988) in what was known as shogai koyo, or 'life-time employment'.

Writers such as Dore (1993) have presented a picture of corporate-society relations as more solidaristic and more akin to the German model than to the Anglo-American. He contrasts the Japanese 'employee community view' with the Anglo-American 'property view' of corporations. Although this image has been unsettled in the last decade following the Asian economic crisis (see below), Dore still contrasts the stock market capitalism of the UK and theUS with the welfare capitalism of Germany and Japan (2000). 
Corporate Social Responsibility (CSR) in Japan: Current Status and Future Challenges,' a CSR survey report released in 2003 by another major Japanese business group, the Japan Association of Corporate Executives ('Keizai Doyukai' in Japanese) defines CSR as an active approach through which more competitive businesses and better societies can be built as a mechanism for synergistic development is created between companies and the society.

Japanese companies have been establishing CSR sections one after another. For example, Ricoh, a Japanese company well known for its excellent environmental management program, drew up its own CSR Charter, the first original charter created by a Japanese company.

The company also established a CSR Division on January 1, 2003. Growing public interest in CSR and the recruitment of new investors will push more Japanese companies to work more seriously on CSR.

Yotaro Kobayashi, chairman of Fuji Zerox and representative of the Japan Association of Corporate Executives, has said that CSR is basically equivalent to Japan's traditional system of business ethics (Nikkei Ecology magazine, June 2004).

The number of symposiums, seminars and lectures on CSR has increased remarkably in Japan in recent years. Phrases such as 'the first CSR year' and 'the CSR boom' are also being used.

CSR is not particularly a new concept. Rather, it's about returning to the fundamental premises that private companies contribute to society through their activities. We'll be keeping you updated on the future development of Japan's CSR movement in our newsletters.

\section{Internet Reporting as an Indicator for CSR in Japan}

Although the per capita Internet use in Japan (44\%) is only 16th in the world, the actual usage is second only to that of the USA. Private use of the Internet has grown from 11 million users in 1997 to almost 56 million by 2001 (from $9.2 \%$ to $44 \%$ of the population).

Increases in business Internet use also reflect these trends: the proportion of medium to large companies (with 300 or more employees) using the Internet grew from $50 \%$ in 1996 to $98 \%$ by 2001 . (6) Thus, there have been clear incentives for corporations to communicate their policies and performances, CSR included, on the Internet.

According to the Internet World Statistics, Japan currently ranks third in the world in the number of Internet users, following China in the first place and the United States in the second CSR Asia has just launched their inuagural Business Barometer, which measures CSR disclosure among the top 20 listed companies in Hong Kong, Malaysia, Singapore and Thailand.

The ranking is based on 62 indicators across the following categories:

1. Company (codes and policies)

2. CSR strategy and communications

3. Marketplace and supply chain

4. Workplace and people

5. The environment

6.Community investment and development.

The findings make interesting reading:

Top Issues - Company (codes and policies) are the most reported CSR issue (scoring $59 \%$ ), compared with workplace and people scoring only $19 \%$. This seems to imply a continued lack of transparency on Malaysia's thorniest CSR issue, namely labour conditions.

Top Countries - The companies' overall score remains low (30\%), but there is some national variation, with Hong Kong scoring best (42\%), as compared with Malaysia (29\%), Thailand (25\%) and Singapore (24\%). 
Top Companies - The top companies China Light and Power and HSBC, both listed in Hong Kong - scored 93\%, as compared with the poorest performer Hong Kong Land, scoring only 3\%. The top company in Malaysia was, somewhat controversially, BAT (British American Tobacco); in Thailand, it was Siam Cement, and in Singapore, City Developments.

What can we understand about CSR in Malaysia from these findings?

1. Lag effect - Transparency and reporting are not a strong tradition in the East (some would even argue that it is contrary to many cultural norms), so companies are playing catch-up on the overall trend. It remains, by and large, an expectation imposed by the West.

2.Large Spectrum - The huge variation between the best and worst performers, as well as the overall poor performance, suggests that there is a general lack of awareness, expectation and standards on CSR reporting in Malaysia.

3. Size Does not Matter - An analysis of the findings showed that there was no correlation between company size and CSR reporting performance. Hence, we need to take other factors into account international aspirations and strength of leadership for example.

4. Implicit CSR - We should remember that CSR reporting does not necessarily equate to CSR performance. It is quite possible that many Malaysian companies, much like in Europe, engage in what Matten \& Moon call "implicit" CSR (as compared with "explicit CSR" in America).

5. Globalisation Matters - However, any Malaysian company now engaged internationally, either through the supply chain or foreign direct investment, will increasingly need to meet minimum standards for transparency (such as the Global Reporting Initiative) and for CSR (such as the Global Compact). Only 5 of the 80 companies were Global Compact signatories.
Our expectation is that we will see overall performace in the Barometer leap up over the coming year or two, as a combination of domestic awareness and international pressure raises CSR further up the politcal and economic agenda in Malaysia.

\section{CSR Activities in Various Companies in Malaysia}

\section{Limitation and Scope of This}

This research gives a detailed CSR scenario of Malaysian industries but due to lack of time, space and information, Japanese industries CSR inputs have been used but not analysed. This can be done in a similar research taken up for considering Japan specifically.

\section{Conclusion and Further Work}

After analyzing these sources along with the electronic media content of the selected companies analyzed, the authors of this study have identified some categories that best fit the activities that the companies were reporting. These are in line with Bursa Malaysia CSR Framework which looks at four main focal areas for CSR practice (Bursa Malaysia, 2008). They are: the environment, the workplace, the community and the marketplace, in no order of priority. For this study, one category is included i.e. social. It is interesting to note that these categories are almost similar to those identified by the Environmental Index Report available for Business in the Community web site Environment Index Report (2005).

An organization reputation is built on its relationship with staff, customers, suppliers, investors and the community they operate within. These stakeholders are the very same that CSR activities seek to involve. This is why CSR can help maintain and enhance repetitions. However, lack of leadership from the top is still a barrier to placing CSR at the heart of business; a state of affairs can be addressed with a leadership agenda to help business leaders relate to the stakeholders. This includes:- 
1. Baseline analysis,

2. Strategic positioning,

3. Engagement,

4. Action.

Finally, our analysis shows that CSR is no longer merely fashionable but an essential component in delivering improved performance, requiring committed leaders to put it at the heart of business.

Hence, the policy makers need to further action, most notably strengthening the existing provisions so that CSR becomes a boon for developing nations.

An NGO's complaint was that Malaysians were showing lukewarm response to both welfare activities and making donations to old folk homes. An NGO told the newspaper how she had set up a Corporate Social Responsibility Foundation to encourage Malaysian children to visit old people. This misuse and misunderstanding of the terminology associated with CSR is frustrating. CSR advocates should not have any problem with philanthropy, but they should not dress it up as CSR when it clearly is not. Here the onus lies on journalists too, who have a responsibility to better brief themselves about what CSR really entails.Newspapers have an obligation to make sure that their reporting is accurate. If CSR is going to be taken seriously by businesses and recognised as a very important part of business strategy locally, then we can look at global markets.

Recommendations based on the findings of Bursa Malaysia to Improve the CSR Status of Malaysian PLC'S:

1. Public Limited companies need to give a higher priority to, and assign appropraite resources to planning and incorporating CSR practices into business operations and to CSR disclosure on the web or the media.

2. It is critical that PLCs should understand key concepts of good CSR practice in order to be able to effectively integrate CSR activities into business operations.

3. Increased efforts to enhance awareness of the importance of CSR both in its business benefits as well as its role in sustainability are needed.

4. Gender or ethical diversity needs attention, as an overly homogeneous workforce often means similar skill sets and life experiences, thereby lacking the different perspectives instrumental in guiding a company in the long run. Encouraging a diverse workforce, management teams and boards ensures companies.

\section{References}

Adams, C. \& Zutshi, A. (2004). "Corporate Social Responsibility: Why Business Should Act Responsibly and be Accountable," Australian Accounting Review, available at http://findarticles.com/p/articles/mi_qa5 395/is_200411/ai_n21361571

Ahmed, N. N. N., Sulaiman, M. \& Siswantoro, D. (2003). "Corporate Social Responsibility Disclosure in Malaysia: An Analysis of Annual Reports of KLSE Listed Companies," IIUM Journal of Economics and Management 11, no.1

Amaeshi, K. \& Adi, B. C. (2006). 'Corporate Social Responsibility as Deinstitutionalization of Corruption in Developing Economies: A Case Study of Nigeria. beyond CSR?,' Business, Poverty and Social Justice Conference 22 May 2006, National Liberal Club, London

Amaeshi, K, Ezeoha, A., Bongo, C., Adi, B. C. \& Manson, N. (2007). 'Financial Exclusion and Strategic Corporate Social Responsibility: A Missing Link in Sustainable Finance Discourse?,' ICCSR Research Paper Series - ISSN 1479-5124 No. 49-2007

AMEinfo. (2005). "Corporate Social Responsibility - an Overview," Available at http://www.ameinfo.com/61308.html, UAE May $30^{\text {th }}$. 
Andrew, B. H., Gul, F. A., Guthrie, J. E. \& Teoh, H. Y. (1989). "A Note on Corporate Social Disclosure Practices in Developing Countries: The Case of Malaysia and Singapore," British Accounting Review 21: 371-376.

Bank Negara Malaysia. (2005). Main SMI Sectors in Malaysia (atas talian) Bernama.Com (2008)." Public Bank Bags Top Honours In Malaysian Business CSR Awards," available from http://www.bernama.com/bernama/v5/n ewsindex.php?id=317455

British Malaysian Chamber of Commerce (BMCC). 2006. (atas talian)

Bursa Malaysia, (2006). "Corporate Social Responsibility (CSR) Framework for Malaysia," available at http://www.bursamalaysia.com/website/ bm/about_us/the_organisation/csr/downl oads/csr_framework_slides.pdf

Bursa Malaysia, (2007). 'Breakfast Dialogue on CSR,' Malaysia Institute of Integrity (IIM). July 26

Bursa Malaysia (2008). 'Corporate Social Responsibility (CSR) Framework for Malaysian Public Listed Companies,' available at http://www.klse.com.my/website/bm/abo ut_us/the_organisation/csr/downloads/csr _writeup.pdf

Chamhuri Siwar \& Wan Noramelia Merican. 2004. Corporate Social Responsibility (CSR).

Chan, WL. (2000)."Corporate Social Responsibility Reporting in Malaysia: Progress and Prospects," The Journal of Corporate Citizenship

CSR Asia Business Barometer (2008). 'Corporate Social Responsibility in Asia, The Issues as They Emerge in the AsiaPacific Region,' The State of CSR Disclosure in Asia

CSR Malaysia (2007)." Leading CSR Bank Eyes Malaysia Expansion," October 6, 2007 CSR Status Report An executive summary, (2007). Corporate Social Responsibility in
Malaysia, CSR Booklet, Bursa Malaysia Berhad.

Dore, R. (1993). 'What Makes Japan Different?,' in C. Crouch and D. Marquand (eds.). Ethics and Markets: Cooperation and Competition within Capitalist Economies (London: Political Quarterly)

Costs CSR in Malaysian PLC's, 2007 Status Report, 'An Executive Summary for R\&D and Financial Performance in Developing Countries: Case Study in Malaysia,' The 2004 Corporate Social Responsibility and Environmental Management Conference Proceedings, Nottingham, hlm. 285-294.

Cowen, S. S., Ferreri, L. B. \& Parker, L. D. 1987."The Impact of Corporate Characteristics on Social Responsibility Disclosure: A Typology and FrequencyBased Analysis," Accounting, Organisations and Society 12 (2): 111-122.

Environment Index Report (2005), Benchmarking Corporate Environmental Engagement, Business in the Community web site, available at http://www.bitc.org.uk/resources/publica tions/environment_index_1.html

European Commission. 2001. 'Promoting a European Framework for Corporate Social Responsibility,' Commission Green Paper 2001(COM(2001)366 Final).

Fox, T. (2005). "Small and Medium-Sized Enterprises (SMEs) and Corporate Social Responsibility," London: International Institute for Environment \& Development (IIED).

Gamble, G. D., Kathy, H., Jackson, C. \& Tollerson, C. D. (1996).'Environmental Dsclosures in Annual Reports,' The International Journal of Accounting, 31(3).

Goliath, (2004). "Corporate Social Responsibility: HR's Leadership Role," Research Quarterly, available from:http://goliath.ecnext.com/coms2/gi_ 0199-3516518/Corporate-socialresponsibility-HR-s.html 
Guthrie, J. \& Parker, L. D. (1989)."Corporate social reporting: a rebuttal of legitimacy theory," Accounting and Business Research, 19(76). 343-352.

Hair, J. F., Anderson, R. E., Tatham, R. L. \& Black, W. C. (1998). Multivariate Data Analysis (5th Edition), New York: Macmillan.

Haniffa, R. M. \& Cooke, T. E. (2005). "The Impact of Culture and Governance on Corporate Social Reporting," Journal of Accounting and Public Policy 24: 391-430.

Hogner, R. H. (1982)."Corporate social reporting: eight decades of development at US steel," Research in Corporate Social Performance and Policy, 4, 243-250.

Holcomb, J. L., Upchurch, R. S. \& Okumus, F. (2007)." Corporate Social Responsibility: What are top Hotel Companies Reporting?" International Journal ofContemporary Hospitality Management Vol. 19 No. 6

Husted, B. W. (2003). Governance Choices for Corporate Social Responsibility: to Contribute, Collaborate or Internalize? Long Range Planning 36: 481-498. http://www.bmcc.org.my/index.php?optio $\mathrm{n}=$ com_content\&task=view\&id=295\&Itemi $\mathrm{d}=56$ (13 April 2007).

http://www.bnm.gov.my/index.php?ch=10 $3 \& \mathrm{pg}=456 \& \mathrm{ac}=526 \& \mathrm{yr}=2005 \quad(2 \quad$ April 2007).

http://www.csr-

Malaysia.com/index.php?id=13373

http://www.klse.com.my/website/bm/abo ut_us/the_organisation/csr/downloads/csr _writeup.pdf

http://www.responsibleresearch.com/Res ponsible_Research_Sustainable_Stock_Exch anges_2010.pdf

http://www.ricoh.com/about/pdf/charter. pdf

http://www.internetworldstats.com/asia/j p.htm http://www.treasury.gov.my/index.php?o

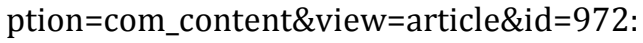
launch-of-bursa-malaysias-csr-frameworkfor-

plcs\&catid=53:ucapan\&Itemid=251\&lang= my

Jenkins, H. M. (2004). 'Corporate Social Responsibility - Engaging Small and Medium Sized Enterprises in the Debate,' Cardiff UK: The Centre for Business Relationships, Accountabiity, Sustainability \& Society (BRASS).

Jenkins, H. \& Yakovleva, N. (2006). "Corporate Social Responsibility in the Mining Industry: Exploring Trends in Social and Environmental Disclosure," Journal of Cleaner Production 14: 271-284.

Macleod, S. (2001). "Why Worry about CSR?," Strategic Communication Management, Vol. 5 No.5, pp.8-9.

Malaysian International Chamber of Commerce \& Industry (MICCI). (2004). (atas talian) http://www.micci.com/main/pmha/info\% 20paper\%2004

Mallen Baker. 2002. The Global Reporting Initiative (GRI) (atas talian) http://www.mallenbaker.net/csr/CSRfiles /GRI.html (13 April 2007).

Mallen Baker.net 2006. Malaysia: Companies Lack Awareness of CSR Potential (atas talian) http://www.mallenbaker.net/csr/CSRfiles /page.php?Story_ID=1372 (30 May 2006).

Nielsen, A. E. \& Thomsen, C. (2007). "Reporting CSR - what and how to say it?" Corporate Communications: An International Journal Vol. 12 No. 1, pp. 2540.

Norhayah Zulkifli, \& Amran Azlan. (2006).'Realising Corporate Social Responsibility in Malaysia; A View from the Accounting Profession,' The Journal of Corporate Citizenship, Dec. 22.

Ogrizek, M. (2004). 'The Effect of Corporate Social Responsibility on the Branding of 
Financialservices', Journal of Financial Services Marketing, 6 (3): 215 -228.

Palmquist, M. (1980) "Content Analysis," Research Methods in Librarianship Techniques and Interpretation. Department of English at Colorado State University available from http://www.ischool.utexas.edu/ palmquis /courses/content.html

Piacentini, M., MacFadyen, L. \& Eadie, D. (2000). "Corporate Social Responsibility in Food Retailing," International Journal of Retail \& Distribution Management, Vol. 28No 11, pp $459-469$.

Ramasamy, B. \& Ting, H. W, (2004)."A Comparative Analysis of Corporate Social Responsibility Awareness," The Journal of Corporate Citizenship, ABI/INFORM Global pg. 109.

Securities Commission. (2003). "SC encourages Malaysian businesses abroad and foreign corporations with Malaysian operations to list on KLSE," (atas talian) http://www.sc.com.my/eng/html/resourc es/press/pr_20030919.html (12 April 2007).

Sekaran, Uma. (2003). Research Methods for Business, A Skill-Building Approach (4th Ed.), New York: John Wiley \& Son Inc.

Sharifah Bakhtiar, Nor Hasimah \& Noor Raida (2008). 'Searching for a Link between the Practice of Environmental Reporting and The Corporate Governance Structure - Recent Evidence from Malaysia,' Conference proceedings at International Colloquium on Asian Business (ICAB).30th June-3rd July 2008.

Small and Medium-Sized Business (SME). (2006). (atas talian) http://www.bitpipe.com/tlist/SmalltoMedium-Sized-Businesses.html (5 Jun 2006).

Small \& Medium Industry Development Corporation (SMIDEC). (2006). SME Performance in the Manufacturing Sector 2003.
Speech by Tan Sri nor Mohamed Yakcop Minister of Finance II Tuesday, 5th of September 2006, at Launch Of Bursa Malaysia's CSR framework For PLC the Putrajaya, Malaysia.

Stemler, S. (2001)."An Overview of Content Analysis," Yale University available from http://pareonline.net/getvn.asp?v=7\&n=1 7

Suza, N. (2005). 'Corporate Social Responsibility in Malaysia,' Nov. 17, available www.oppapers.com/esays/corporate social responsibility-Malaysia/70764,

Szekely, F. \& Knirsch, M. (2005). "leadership and Corporate Responsibility Metrics for Sustainable Corporate Performance. Berlin: Centre for Responsible Leadership andSustainable Futures," European School of Management and Technology.

Taka, Iwao (2002). 'CSR and Corporate Role,'

Tange, H. (2001). 'Kigyo Keiei no Syakaisei Kenkyu (A Study of the Social Nature of Corporate Management)' (Tokyo: Chuo Keiza sha).

Wokutch, R. E. \& Shepard, J. M.( 1999). "The Maturing of The Japanese Economy: Corporate Social Responsibility Implications," Business Ethics Quarterly 9(3). 527-540.

www.unctad.org/en/docs//webdiaeia201 11_en.pdf - Global Investment Trends Monitor.

Yamagami, T. \& Kokubu, K. (1991). "A Note on Corporate Social Disclosure in Japan," Accounting Auditing and Accountability Journal, 4(4). 32-39.

Yusli Mohamed Yusoof. (2007).'Bursa Malaysia- Malaysia Institute of Integrity (IIM) Breakfast Dialogue on,' Bursa Malaysia, available from http://www.klse.com.my/ website/bm /media 
_centre/speeches/downloads/speech_260

707.pdf

Zauwiyah, Salleh \& Junaini. (2003).' Determinants of Environmental Reporting in Malaysia,' International Journal of

Business Studies, Vol 11, No. 1, pages 69-90. 